$\begin{array}{ll}\begin{array}{ll}\text { Australian Journal of } \\ \text { Crop Science }\end{array} & \mathcal{A} \mathrm{CS} \\ \text { AJCS 15(06):955-959 (2021) } & \text { ISSN:1835-2707 }\end{array}$

doi: 10.21475/ajcs.21.15.06.p3245

\title{
Thermal-biological aspects of germination of seeds in tropical forest tree species
}

\author{
Luan Danilo Ferreira de Andrade Melo ${ }^{1 *}$, João Luciano de Andrade Melo Junior ${ }^{1}$, Larice Bruna Ferreira \\ Soares ${ }^{2}$, Lívia Francyne Gomes Chaves ${ }^{1}$, João Correia de Araújo Neto ${ }^{1}$, Vilma Marques Ferreira ${ }^{1}$, Maria \\ Inajal Rodrigues da Silva das Neves ${ }^{1}$, Edilma Pereira Gonçalves ${ }^{2}$, Jeandson Silva Viana ${ }^{2}$, Reinaldo de \\ Alencar Paes ${ }^{1}$, Jaqueline Figueredo de Oliveira Costa ${ }^{1}$, Wesley Oliveira de Assis ${ }^{1}$
}

\author{
${ }^{1}$ Department of Agronomy, University Federal of Alagoas - UFAL, Brazil \\ ${ }^{2}$ Department of Agronomy, University Federal of Agreste of Pernambuco, UFAPE, Brazil
}

*Corresponding author: luan.danilo@yahoo.com.br

\begin{abstract}
The present study was carried out with the objective of evaluating the ecological and applied aspects of temperature in the germination of Colubrina glandulosa (Rhamnaceae), Chloroleucon dumosum (Fabaceae), Enterolobium contortisiliquum (Fabaceae), Mimosa bimucronata (Fabaceae) and Sapindus saponaria (Sapindaceae). Then we assessed germination, average germination time, germination uniformity and germination activation energy as a function of temperatures. The experiment was conducted at the Plant Propagation Laboratory, on the Engineering and Agricultural Sciences Campus, at the Federal University of Alagoas, Rio Largo, AL, Brazil. The experimental design was completely randomized with four replications of 25 seeds per treatment. The data were subjected to analysis of variance and the means were compared using the Tukey test at $5 \%$ probability. The isothermal incubation was performed in Biochemical Oxigen Demand (B.O.D.) germination chamber, at constant temperatures of 5, 10, 15, 20, 25, 30, 35

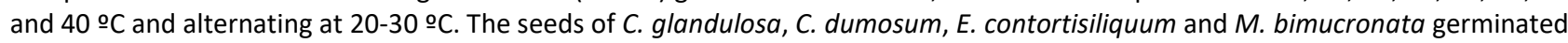
in the range of $10 \circ \mathrm{C} \leq \mathrm{T} \leq 35 \circ \mathrm{\circ}$, and $\mathrm{S}$. saponaria germinated in the range of $20 \circ \mathrm{C} \leq \mathrm{T} \leq 35 \circ \mathrm{C}$. We found that seeds in the optimal temperature range has unimodal distribution of relative frequency, concentrating germination in the shortest time. The activation

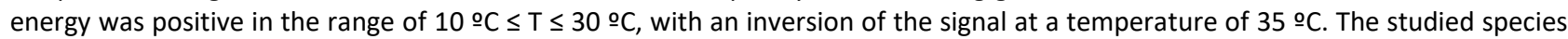
had a wide range of temperature tolerance and the speed was curvilinearly dependent on them. The germination process is predominantly endergonic.
\end{abstract}

Keywords: Caatinga, Activation energy, Atlantic Forest, Northeast.

Abbreviations: BOD_Biochemical Oxygen Demand; SISVAR_System for Analysis of Variance; CECA_Engineering and Agricultural Sciences Campus; UFAL_Federal University of Alagoas.

\section{Introduction}

The Atlantic Forest is a biome representing one of the most complex species diversity on the planet and the Caatinga is the only biome exclusively Brazilian, which means that a large part of its biological heritage cannot be found elsewhere. However, these assets are threatened. Currently, $7.3 \%$ of its original cover remains in the Atlantic Forest and about $70 \%$ of the Caatinga is already altered by human. This is a consequence of predatory exploitation. Particularly in the coastal and semi-arid region of the Northeast, changes in natural landscapes present risks for several species. These regions are home to distribution centers for several families, with some species widely used in reforestation, such as Colubrina glandulosa (Rhamnaceae), Chloroleucon dumosum (Fabaceae), Enterolobium contortisiliquum (Fabaceae), Mimosa bimucronata (Fabaceae) and Sapindus saponaria (Sapindaceae), known as colubrina, arapiraca, monkey's ear, maricá and soap dish, respectively (Lorenzi, 2000; Melo Junior et al., 2018; Melo et al., 2018; Neves et al., 2018).

The seeds are the vehicles of the genetic characteristics of a species. Therefore, for the implantation of any culture, this input must be the first concern. The production technology must start with the use of good quality seeds. In assessing the physiological quality of seeds, the germination test is routinely used. However, in the Rules for Seed Analysis (Brazil, 2009) and in the Instructions for Analysis of Seed of Forest Species (Brazil, 2013), which is still being updated, there is a lack of specific information on the germination ecophysiology of the species in question, which still does not have the criteria established for the standardization of the methods of analysis, in view of the production of seedlings. According to Oliveira et al. (2016) temperature is one of the main environmental factors that governs seed germination, as it strongly influences both the speed of water imbibition by the seed and the biochemical reactions that determine the entire process. In this way, temperature variations affect the speed, percentage and uniformity of germination (Carvalho and Nakagawa, 2012). Each species has a temperature range where germination will occur: temperature or temperature range, considered optimal, where the efficiency of the process is total, and extreme limits of maximum and minimum tolerated by the seeds, above or below, respectively, germinability is not measurable (Bastos et al., 2017). Therefore, it is expected that species with different 
geographical and ecological distributions produce seeds with variations in terms of thermal requirements for germination. Based on this, the present study was carried out with the objective of evaluating the ecological and applied aspects of temperature in the germination of seeds of $C$. glandulosa, $C$. dumosum, E. contortisiliquum, M. bimucronata and $S$. saponaria, verifying the germination, the average germination time, germination uniformity and germination activation energy as a function of temperatures.

\section{Results and discussion}

\section{Germination rate and germination time}

Seeds of Colubrina glandulosa, Chloroleucon dumosum, Enterolobium contortisiliquum and Mimosa bimucronata germinated in the range of $10 \stackrel{\circ}{\circ} \leq \mathrm{T} \leq 35 \stackrel{\circ}{\circ}$, and Sapindus saponaria seeds germinated in the range of $20 \circ \mathrm{C} \leq \mathrm{T} \leq 35$ o $\mathrm{C}$ (Table 1). These results probably occurred due to the physiological adaptation of these seeds to the places of occurrence in dry tropical forest areas.

The optimum temperature for seeds of Colubrina glandulosa, Chloroleucon dumosum, Enterolobium contortisiliquum and Sapindus saponaria was found in the range of $25 \circ \mathrm{o}<\mathrm{T}<30$ oC, and for seeds of Mimosa bimucronata in the range of 20 oc $<T<30$ o $C$, which enabled greater germination (G) in less germination time (TG) (Tables 1 and 2). However, adaptive plasticity dissipation has occurred, since these species also can establish themselves naturally in the Atlantic Forest, Seasonal Semideciduous Forest and Seasonal Deciduous Forest.

Similar results regarding thermal requirements were found for other tree species in the Northeast region of Brazil: Amburana cearensis (Almeida et al., 2017), Mimosa tenuiflora (Benedito et al., 2017), Senegalia bahiensis (Lima et al., 2017) and Mimosa ophthalmocentra (Nogueira et al., 2017).

It was found that seeds submitted to temperatures, in the optimum range, presented supposed unimodal distribution of the relative frequency, concentrating the $G$ in the lowest $T G$ (Tables 1 and 2).

\section{Germination uniformity and germination activation energy} For seeds of Colubrina glandulosa, Chloroleucon dumosum, Enterolobium contortisiliquum and Sapindus saponaria, germination uniformity (U) was lower in the range of $20 \stackrel{\circ}{ } \mathrm{C} \geq$ $\mathrm{T} \geq 35^{\circ} \mathrm{C}$, and for Mimosa bimucronata seeds the $\mathrm{U}$ was lower in the range of $15{ }^{\circ} \mathrm{C} \geq \mathrm{T} \geq 35 \stackrel{\circ}{\circ} \mathrm{C}$ (Table 3 ). In turn, in these intervals, there was possibly a polymodal distribution of the relative frequency and a greater degree of spreading of the $G$ along the TG.

This strategy provided efficiency in the establishment of seedlings, because the seeds can produce seedlings that they may find, ideal conditions for their development (Oliveira et al., 2017). The ecological implications for tropical and subtropical areas, especially in summer, can be an advantageous alternative for the establishment of Colubrina glandulosa, Chloroleucon dumosum, Enterolobium contortisiliquum and Mimosa bimucronata.

For this reason, higher environmental temperatures, such as those expected as a result of global warming, may increase germination reproduction (Sanhueza et al., 2017). In addition, it was observed that the increases in the populations of existing Sapindus saponaria would be caused by an improvement in their reproductive performance as a result of regional warming.
The germination activation energy $(\Delta \mathrm{H})$ for seeds of Colubrina glandulosa, Chloroleucon dumosum and Enterolobium

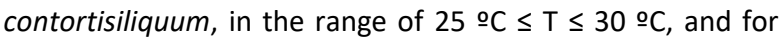

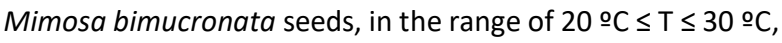
was less than $12 \mathrm{Kcal}$ (Table 4). Therefore, the lower the $\Delta \mathrm{H}$ consumed in the TG, caused more efficiency in seedling development.

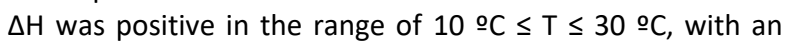
inversion of the signal at a temperature of $35 \stackrel{\circ}{ } \mathrm{C}$ (Table 4).

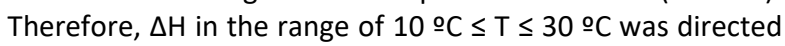
towards the resumption of growth by the embryonic axis (Silva et al., 2017). On the other hand, at a temperature of 35 o $\mathrm{C}$, the mobilized $\Delta \mathrm{H}$ was also diverted to any other process not linked to the process of resuming embryo growth (Medeiros et al., 2017).

\section{Material and Methods}

\section{Location}

The experiment was conducted at the Plant Propagation Laboratory, on the Engineering and Agricultural Sciences Campus, at the Federal University of Alagoas, Rio Largo, AL, Brazil.

\section{Plant materials}

To obtain the seeds, ripe fruits were harvested from January to December 2019, from trees belonging to forest fragments located in the state of Alagoas, Brazil located at $09^{\circ} 10^{\prime} 11^{\prime \prime} \mathrm{S}$, $36^{\circ} 40^{\prime} 47^{\prime \prime} \mathrm{W}$ and 654 meters above sea level. According to the Köppen climate classification, the climate is BSh type, hot semi-arid (Emperaire, 1984).

The fruits were harvested at the end of the maturation period with aerial scissors with an extension cord and then kept in the shade (shelter protected from the sun and rain) for a few days, to complete the drying process and facilitate the dehiscence of the fruits (Melo Junior et al., 2018).

The isothermal incubation was carried out in a germination chamber of the BOD type, at constant temperatures of 5,10 , $15,20,25,30,35$ and $40{ }^{\circ} \mathrm{C}$ and alternating at 20-30 $\mathrm{C}$, with a photoperiod of eight hours, simulated for four daylight-type $20 \mathrm{~W}$ fluorescent lamps. The accuracy of the temperature control was within the range of $\pm 0.5 \stackrel{\circ}{\circ}$. To install the germination test, first, the seeds were sterilised by immersion in $70 \%$ alcohol for 1 minute, followed by washing in running water (Rios et al., 2016). Subsequently, topping with scissors was used in the region opposite the hilum, with the seeds placed to germinate on two sheets of paper towels moistened with a volume of distilled water equivalent to 2.5 times the weight of dry paper (Brazil, 2009), contained in transparent plastic boxes $(11.0 \times 11.0 \times 3.5 \mathrm{~cm})$.

The germinated seeds were counted daily for 19 days ( $C$. glandulosa), 15 days (C. dumosum), 15 days ( $E$. contortisiliquum), 15 days ( $M$. bimucronata) and 45 days ( $S$. saponaria), from the test installation. The subsequent addition of waterwas carried out when necessary to ensure that the substrate remained sufficiently moist throughout the entire experiment. At constant temperatures of 5, 10 and 15 oC, the test was extended for another seven days, transferring the seeds to the ideal temperature.

\section{Variables analyzed}

Germinability: $g i=(\Sigma k i=1 \mathrm{ni} / \mathrm{N}) \times 100$ (Carvalho; Santana; Ranal, 2005), ni being the number of seeds germinated in time $i$ and $\mathrm{N}$ the total number of seeds placed to germinate. 
Table 1. Germination (\%) of seeds of tropical tropical tree species, under different temperatures.

\begin{tabular}{|c|c|c|c|c|c|}
\hline Temperature $(\stackrel{\circ}{ } \mathrm{C})$ & $\begin{array}{l}\text { Colubrina } \\
\text { glandulosa }\end{array}$ & $\begin{array}{l}\text { Chloroleucon } \\
\text { dumosum }\end{array}$ & $\begin{array}{c}\text { Enterolobium } \\
\text { contortisiliquum }\end{array}$ & $\begin{array}{c}\text { Mimosa } \\
\text { bimucronata }\end{array}$ & $\begin{array}{l}\text { Sapindus } \\
\text { saponaria }\end{array}$ \\
\hline 10 & 13 e & $8 \mathrm{e}$ & $9 \mathrm{f}$ & $5 \mathrm{e}$ & $1 d$ \\
\hline 15 & $31 \mathrm{~d}$ & $17 d$ & $32 \mathrm{e}$ & $33 d$ & $1 d$ \\
\hline 20 & $60 c$ & $30 \mathrm{c}$ & $77 c$ & $93 \mathrm{~b}$ & $2 \mathrm{~d}$ \\
\hline 25 & $72 \mathrm{~b}$ & $73 \mathrm{~b}$ & $83 \mathrm{~b}$ & $94 \mathrm{~b}$ & $54 \mathrm{~b}$ \\
\hline 30 & $98 \mathrm{a}$ & $87 a$ & 99 a & 99 a & $67 a$ \\
\hline 35 & $27 d$ & $14 d$ & $48 d$ & $69 c$ & $24 c$ \\
\hline $20-30$ & $59 \mathrm{c}$ & $29 c$ & $76 \mathrm{c}$ & $92 \mathrm{~b}$ & $58 \mathrm{~b}$ \\
\hline Value "F" & $492.71^{* *}$ & $243.32 * *$ & $453.25 * *$ & $409.70 * *$ & $240.32 * *$ \\
\hline CV (\%) & 7.85 & 9.85 & 8.43 & 10.01 & 14.12 \\
\hline
\end{tabular}

Averages followed by the same lower case letter in the column do not differ at $5 \%$ probability by the Tukey test.

** Significant at the $1 \%$ probability level.

Table 2. Germination time (days) of seeds of tree species from tropical forests, under different temperatures.

\begin{tabular}{|c|c|c|c|c|c|}
\hline Temperature $\left({ }^{\circ} \mathrm{C}\right)$ & $\begin{array}{c}\text { Colubrina } \\
\text { glandulosa }\end{array}$ & $\begin{array}{c}\text { Chloroleucon } \\
\text { dumosum }\end{array}$ & $\begin{array}{c}\text { Enterolobium } \\
\text { contortisiliquum }\end{array}$ & $\begin{array}{c}\text { Mimosa } \\
\text { bimucronata }\end{array}$ & $\begin{array}{c}\text { Sapindus } \\
\text { saponaria }\end{array}$ \\
\hline 10 & $13 \mathrm{f}$ & $14 \mathrm{e}$ & $13 \mathrm{e}$ & $10 \mathrm{e}$ & $30 \mathrm{~d}$ \\
\hline 15 & $11 \mathrm{e}$ & $12 \mathrm{~d}$ & $10 \mathrm{~d}$ & $6 \mathrm{~d}$ & $30 \mathrm{~d}$ \\
\hline 20 & $7 \mathrm{~d}$ & $9 \mathrm{c}$ & $8 \mathrm{c}$ & $6 \mathrm{~b}$ & $15 \mathrm{~b}$ \\
\hline 25 & $5 \mathrm{~b}$ & $7 \mathrm{~b}$ & $7 \mathrm{~b}$ & $4 \mathrm{a}$ & $14 \mathrm{a}$ \\
\hline 30 & $4 \mathrm{a}$ & $6 \mathrm{a}$ & $5 \mathrm{a}$ & $7 \mathrm{c}$ & $19 \mathrm{c}$ \\
\hline 35 & $6 \mathrm{c}$ & $12 \mathrm{~d}$ & $8 \mathrm{c}$ & $6 \mathrm{~b}$ & $15 \mathrm{~b}$ \\
\hline $20-30$ & $5 \mathrm{~b}$ & $9 \mathrm{c}$ & $7 \mathrm{~b}$ & $337.18^{* *}$ & $359.12^{* *}$ \\
\hline Value "F" & $1158.58^{* *}$ & $724.38^{* *}$ & $946.46^{* *}$ & 9.05 & 13.43 \\
\hline CV (\%) & 6.61 & 8.42 & 7.33 & & 30 \\
\hline
\end{tabular}

Averages followed by the same lower case letter in the column do not differ at $5 \%$ probability by the Tukey test. ${ }^{*}$ Significant at the $1 \%$ probability level.

Table 3. Germination uniformity (bit) of seeds of tree species from tropical forests, under different temperatures.

\begin{tabular}{|c|c|c|c|c|c|}
\hline Temperature $\left({ }^{\circ} \mathrm{C}\right)$ & $\begin{array}{c}\text { Colubrina } \\
\text { glandulosa }\end{array}$ & $\begin{array}{c}\text { Chloroleucon } \\
\text { dumosum }\end{array}$ & $\begin{array}{c}\text { Enterolobium } \\
\text { contortisiliquum }\end{array}$ & $\begin{array}{c}\text { Mimosa } \\
\text { bimucronata }\end{array}$ & $\begin{array}{c}\text { Sapindus } \\
\text { saponaria }\end{array}$ \\
\hline 10 & $2.5105 \mathrm{f}$ & $2.7317 \mathrm{e}$ & $2.6216 \mathrm{e}$ & $2.5216 \mathrm{e}$ & $2.9821 \mathrm{~d}$ \\
\hline 15 & $2.4078 \mathrm{f}$ & $2.6208 \mathrm{~d}$ & $2.4168 \mathrm{~d}$ & $2.3258 \mathrm{~d}$ & $2.9822 \mathrm{~d}$ \\
\hline 20 & $2.2147 \mathrm{e}$ & $2.1183 \mathrm{c}$ & $1.9325 \mathrm{c}$ & $1.4502 \mathrm{~b}$ & $2.9733 \mathrm{~d}$ \\
\hline 25 & $1.4577 \mathrm{~b}$ & $1.5599 \mathrm{~b}$ & $1.5588 \mathrm{~b}$ & $1.3588 \mathrm{~b}$ & $2.5833 \mathrm{~b}$ \\
\hline 30 & $0.9072 \mathrm{a}$ & $0.9978 \mathrm{a}$ & $0.9475 \mathrm{a}$ & $0.9777 \mathrm{a}$ & $1.4155 \mathrm{a}$ \\
\hline 35 & $2.0733 \mathrm{~d}$ & $2.6319 \mathrm{~d}$ & $1.9834 \mathrm{c}$ & $2.0834 \mathrm{c}$ & $2.7501 \mathrm{c}$ \\
\hline $20-30$ & $1.6325 \mathrm{c}$ & $2.1436 \mathrm{c}$ & $1.5546 \mathrm{~b}$ & $1.4766 \mathrm{~b}$ & $2.5944 \mathrm{~b}$ \\
\hline Value "F" & $1352.75^{* *}$ & $191.11^{* *}$ & $734.53 * *$ & $27.31 * *$ & $174.09^{* *}$ \\
\hline CV (\%) & 5.47 & 12.74 & 9.37 & 14.16 & 14.01 \\
\hline
\end{tabular}

Averages followed by the same lower case letter in the column do not differ at $5 \%$ probability by the Tukey test.

** Significant at the $1 \%$ probability level.

Table 4. Germination activation energy (Kcal) of tree species from tropical forests, under different temperatures.

\begin{tabular}{|c|c|c|c|c|c|}
\hline Temperature $\left({ }^{\circ} \mathrm{C}\right)$ & $\begin{array}{c}\text { Colubrina } \\
\text { glandulosa }\end{array}$ & $\begin{array}{c}\text { Chloroleucon } \\
\text { dumosum }\end{array}$ & $\begin{array}{c}\text { Enterolobium } \\
\text { contortisiliquum }\end{array}$ & $\begin{array}{c}\text { Mimosa } \\
\text { bimucronata }\end{array}$ & $\begin{array}{c}\text { Sapindus } \\
\text { saponaria }\end{array}$ \\
\hline 10 & 31.18 & 34.75 & 32.26 & 33.31 & 37.64 \\
\hline 15 & 32.29 & 34.42 & 26.13 & 20.07 & 37.42 \\
\hline 20 & 17.38 & 32.30 & 14.16 & 9.97 & 35.53 \\
\hline 25 & 10.07 & 9.99 & 9.85 & 9.64 & 18.49 \\
\hline 30 & 9.42 & 9.78 & 9.47 & 9.53 & 15.77 \\
\hline 35 & -37.24 & -37.57 & -31.94 & -26.65 & -38.35 \\
\hline
\end{tabular}

Average germination time: $t=\Sigma k i=1$ (niti) $/ \Sigma k i=1 \mathrm{ni}$ (Czabator, 1962), Where: ti: time from the beginning of the experiment to the $i$ nth observation (days or hours); ni: number of seeds germinated in time $i$ (number corresponding to $i$ nth observation); $k$ : last day of germination.

Germination uniformity: $\mathrm{U}=-\Sigma k i=1 \mathrm{Filog} 2 \mathrm{Fi} \approx \mathrm{Fi}=\mathrm{ni} / \Sigma k i=$ 1ni (Labouriau, 1983), with $\mathrm{Fi}$ : relative germination frequency; ni: number of seeds germinated in time $i$ (number corresponding to $i$ nth observation); $k$ : last day of germination. Synchrony index: $Z=\Sigma \mathrm{Cn} 1,2 / N=\mathrm{Cn} 1,2=\mathrm{ni}$ ( $\mathrm{ni}$
- 1) / 2; N = $\sum$ ni $\left(\sum n i-1\right) / 2$ (Primack, 1980), where Cn1,2 is the combination of seeds germinated in the $i$ th time and ni the number of seeds germinated in time

From the Arrhenius equation - $(-R \ln V) / \partial(1 / T)=\Delta H \neq+R T$, the net variation of energy (enthalpy) for germination activation was calculated both in the infra (V1) and in the above range optimal (V2), using the minimum ( $\mathrm{Tm}$ ) and maximum (TM) germination temperatures as parameters (Labouriau and Labouriau, 1997). Thus, in band V1, $\Delta \mathrm{H} \neq 1=$ R.Tm. [T / $(T-T m)]$, and in band V2, $\Delta H \neq 2=-R . T M$. [ $T /(T M$ 
- T)], the net variation of enthalpy $(\Delta H \neq)$ as a function of temperature was represented by the expression (Labouriau, 1978): $\Delta H \neq=[R T(\theta-T) .(T m+T M)] /[(T-T m(T M-T)]$, where $\theta$ (harmonic mean of minimum and maximum temperatures) $=[(2 T m \cdot T M) /(T m+T M)]$, and $T$ is the experimental temperature, following the physiological interpretation of the opposite signs of $\Delta \mathrm{H} \neq$ in the infra and supra-optimal germination ranges.

\section{Statistical analysis}

The experimental design was completely randomized, with four replications of 25 seeds per treatment. The data were subjected to analysis of variance and the means were compared using the Tukey test at $5 \%$ probability. The statistical program used was Sisvar version 5.6 (Ferreira, 2011).

\section{Conclusions}

The seeds of the studied species showed a wide range of temperature tolerance, with minimum and maximum limits of 10 and $35 \circ$ ㅇ, respectively. The optimum temperature for germination of the analyzed species is $30 \stackrel{\circ}{ }$, the speed of which depends on the temperature. The germination process is of the species is predominantly endergonic.

\section{Acknowledgment}

Thanks to National Council for Scientific and Technological Development - CNPq for the financial support of the Research Project.

\section{References}

Almeida JPN, Lessa BFT, Pinheiro CL, Gomes FM, Medeiros Filho S, Silva CC (2017) Germination and development of Amburana cearensis seedlings as influenced by seed weight, light and temperature. Acta Sci Agron. 39(4): 525-533. https://doi.org/10.4025/actasciagron.v39i4. 32786

Bastos LLS, Ferraz IDK, Lima Junior MJV, Pritchard HW (2017) Variation in limits to germination temperature and rates across the seed-seedling transition in the palm Oenocarpus bataua from the Brazilian Amazon. Seed Sci Techno. 45(1): 2017.

Benedito $C P$, Ribeiro MCC, Torres SB, Guimarães IP, Oliveira KJB (2017) Dormancy overcoming, temperatures and substrates on germination of Mimosa tenuiflora Willd seeds. Semina: Ciênc Agrár. 38(1): 125134. https://doi.org/10.5433/1679-0359.2017v38n1p125

Brasil (2013) Ministério da Agricultura, Pecuária e Abastecimento. Instruções para análise de sementes de espécies florestais. Ministério da Agricultura, Pecuária e Abastecimento. Secretaria de Defesa Agropecuária/Coordenação Geral de Apoio Laboratorial. Brasília, DF: MAPA/SDA/CGAL, $97 \mathrm{p}$.

Brasil (2009) Ministério da Agricultura, Pecuária e Abastecimento. Secretaria de Defesa Agropecuária. Regras para análise de sementes. Brasília, DF, 395p.
Carvalho MP, Santana DG, Ranal MA (2005) Emergência de plântulas de Anacardium humile A. St.-Hil. (Anacardiaceae) avaliada por meio de amostras pequenas. Rev Bras Bot. 28(3): 627-633.

Carvalho NM, Nakagawa J (2012). Sementes: ciência, tecnologia e produção. Jaboticabal: FUNEP, 5: 590.

Czabator FJ (1962) Germination value: an index combining speed and completeness of pine seed germination. Forest Sci. 8(4): 386-396.

Emperaire LA (1984). Região da Serra da Capivara (Sudeste do Piauí) e sua vegetação. Brasil Florestal 13(60): 5-21.

Ferreira DF (2011) Sisvar: a computer statistical analysis system. Ciênc e Agrotec. 35(6): 1039-1042. https://doi.org/10.1590/S1413-70542011000600001

Labouriau LG (1983) A germinação de sementes. Secretaria Geral da OEA, Washington- Programa Regional de Desenvolvimento Científico e Tecnológico, Washington, $174 \mathrm{p}$.

Labouriau LG (1978) Seed germination as a thermobiological problem. Radiat Environ Biophys. 15(4): 345-366.

Labouriau LG, Labouriau IS (1997) Physiological rate processes form the point of view of absolute reaction rate theory. Ciênc Cult. 49(3): 177-189.

Lima TM, Mendonça AVR, Paixão CC, Freitas TAS, Moreira RFC (2017) Influence of temperature and photoperiod on the germination of Senegalia bahiensis seeds. Semina: Ciên Agrár 38(3): 1103-1114. https://doi.org/10.5433/1679-0359.2017v38n3p1103

Lorenzi H (2000) Árvores brasileiras: manual de identificação e cultivo de plantas arbóreas nativas do Brasil. Nova Odessa: Instituto Plantarum. 1(3): 352.

Melo Junior JLA, Melo LDFA, Araújo Neto JC, Ferreira VM (2018) Germination and morphology of seeds and seedlings of Colubrina glandulosa Perkins after overcoming dormancy. Aust J Crop Sci. 12(4):639-647.

Melo LDFA, Melo Junior JLA, Ferreira VM, Araujo Neto JC, Neves MIRS (2018). Biometric characterization and seed germination of giant mimosa (Mimosa bimucronata (DC) O. Kuntze). Aust J Crop Sci. 12: 108-115.

Neves MIRS, Araújo Neto JC, Ferreira VM, Silva CB, Melo Júnior JL, Melo LDFA, Farias AS, Galvão ER, Silva VSG (2018) Morphometric Characterization and Seed Dormancy Overcoming of Sapindus saponaria L. J Agri Science. 10:329-341.

Nogueira NW, Torres S B, Freitas RMO, Castro THS, Sá FVS (2017) 'Jurema-de-embira' seed germination under water stress and at different temperatures. Ver Bras Eng Agrí e Amb. 21(4): 244-248. https://doi.org/10.1590/18071929/agriambi.v21n4p244-248

Oliveira FN, França FD, Torres SB, Nogueira NW, Freitas RMO (2016) Temperaturas e substratos na germinação de sementes de pereiro-vermelho (Simira gardneriana M.R. Barbosa \& Peixoto). Rev Ciênc Agro 47(4):658-666.

Oliveira FN, Oliveira JR, Torres SB, Freitas RMO, Nogueira NW (2017) Germination and initial development of Simira gardneriana seedling under water stress and at different temperatures. Rev Bras Eng Agrí e Amb 2(5):333-338. https://doi.org/10.1590/1807-1929/ agriambi.v21n5p333-338 
Rios PAF, Araújo Neto JC, Ferreira VM, Neves MIRS (2016) Seed morphometry and germination of Aechmea costantinii (Mez) L. B. Sm. (Bromeliaceae). Rev Caatinga 29(1): 85-93.
Sanhueza C, Vallejos V, Cavieres LA, Saez P, Bravo LA, Corcuera $\amalg$ (2017) Growing temperature affects seed germination of the antarctic plant Colobanthus quitensis (Kunth) Bartl (Caryophyllaceae). Polar Biol 40(2): 449455. https://doi.org/10.1007/s00300-016-1972-4. 